\title{
Pemodelan Hidrodinamika 3-Dimensi Pola Persebaran Sedimentasi Pra dan Pasca Reklamasi Teluk Jakarta
}

\author{
Evasari Aprilia dan Danar Guruh Pratomo \\ Departemen Teknik Geomatika, Fakultas Teknik Sipil dan Perencanaan, Institut Teknologi Sepuluh Nopember \\ (ITS) \\ e-mail: guruh@geodesy.its.ac.id
}

\begin{abstract}
Abstrak-Teluk Jakarta merupakan perairan laut Jawa yang terletak di sebelah utara provinsi DKI Jakarta, Indonesia. Dilokasi tersebut, tingginya laju sedimentasi telah teridentifikasi sejak awal tahun 1970-an sebagai akibat dari perubahan yang terjadi di daerah hulu dan sepanjang aliran sungai-sungai yang mengalir ke Teluk Jakarta. Sesuai dengan Peraturan Daerah No.1 tahun 2012 tentang Rencana Tata Ruang Wilayah DKI Jakarta 2030, luas lahan reklamasi yang direncanakan meliputi 17 pulau dengan luas kurang lebih 5.100 ha. Dalam penelitian ini dilakukan simulasi pemodelan arus dan pola sebaran sedimen di Teluk Jakarta menggunakan beberapa parameter seperti data batimetri, data pasang surut, data garis pantai, data river discharge dari 5 sungai yang bermuara ke Teluk Jakarta, dan data curah hujan. Simulasi dilakukan menggunakan dua skenario, yaitu pra diadakannya reklamasi (bulan Januari dan September 2011) dan pasca diadakan reklamasi (bulan Februari dan Mei 2016). Kecepatan arus rata-rata saat pra reklamasi mencapai angka $0,94 \mathrm{~m} / \mathrm{s}$ sedangkan pasca mencapai nilai rata-rata $0,88 \mathrm{~m} / \mathrm{s}$. Pasca diadakan reklamasi juga terjadi peningkatan ketebalan sedimen dasar perairan hingga mencapai 2,49 m dibandingkan kondisi saat sebelum reklamasi yang hanya mencapai ketebalan maksimum sebesar $0,84 \mathrm{~m}$. Konsentrasi sedimen tertinggi terjadi pada lokasi yang berada didekat dengan Muara Cengkareng yang salah satunya disebabkan oleh debit harian sungai yang cukup tinggi di lokasi tersebut.
\end{abstract}

Kata kunci-Pemodelan Hidrodinamika, Reklamasi Teluk Jakarta, Pola Sedimentasi.

\section{PENDAHULUAN}

$\mathrm{T}$ ELUK Jakarta merupakan perairan laut Jawa yang terletak di sebelah utara provinsi DKI Jakarta, Indonesia. Teluk ini merupakan wilayah perairan dangkal dengan kedalaman perairan rata-rata mencapai 15 meter [1]. Sejak tahun 1970-an salah satu permasalahan utama diperairan tersebut adalah permasalahan terkait sedimentasi. Laju sedimentasi terus meningkat disebabkan oleh perubahan yang terjadi di daerah hulu dan sepanjang aliran sungai-sungai yang mengalir ke Teluk Jakarta [2]. Teluk Jakarta memliki keadaan morfologi dasar perairan yang terbentuk oleh hasil endapan sedimen sungai [3]. Sedimen laut Teluk Jakarta memiliki tekstur tanah lempung liat berpasir atau biasa dikenal dengan jenis sedimen kohesif [2]. Pada dasarnya sumber sedimen kohesif di daerah estuari dan perairan teluk umumnya berasal dari limpasan daratan (run off) hujan yang masuk ke badan sungai atau langsung ke perairan pesisir.
Sejak tahun 1990, Pemerintah Republik Indonesia memiliki rencana untuk melakukan penataan kembali Kawasan Teluk Jakarta dengan konsep reklamasi pulau dan konsep revitalisasi pantai lama. Sesuai dengan Peraturan Daerah No.1 tahun 2012 tentang Rencana Tata Ruang Wilayah DKI Jakarta 2030[4], luas lahan reklamasi yang direncanakan meliputi 17 buah pulau dengan luas kurang lebih 5.100 ha. Reklamasi pada dasarnya merupakan kegiatan atau upaya yang dilakukan oleh orang/kelompok orang atau pengembang (developer) dengan mengubah lahan basah dengan cara dikeringkan atau cara ditimbun, sehingga dihasilkan lahan atau tanah kering yang digunakan untuk kegiatan pembangunan. Salah satu dampak yang dikhawatirkan oleh adanya reklamasi adalah semakin meningkatnya konsentrasi sedimen di Teluk Jakarta. Jika laju sedimentasi meningkat, maka pendangkalan di Teluk Jakarta akan semakin cepat dan dapat berdampak ke permasalahan lainnya [4].

Pengetahuan mengenai dinamika perairan sangat penting untuk dipahami sebagai upaya untuk memprediksi persebaran sedimen setelah diadakannya reklamasi. Pendekatan yang dilakukan untuk mengetahui pola arus dan sedimen adalah melalui aplikasi model matematik/numerik. Hasil model yang telah divalidasi dan telah menunjukkan korelasi atau kemiripan dengan kondisi sebenarnya di lapangan dapat digunakan untuk memprediksi dinamika berbagai proses yang terjadi di perairan [5]. Pada penelitian ini, diharapkan dapat dilakukannya pemodelan numerik menggunakan software pemodelan hidrodinamika dan sedimen untuk mengetahui pola sedimentasi di Teluk Jakarta pada baik pra dan pasca diadakannya reklamasi. Kemudian diharapkan dapat menganalisis pola sedimentasi di Teluk Jakarta pra dan pasca reklamasi.

\section{METODOLOGI PENELITIAN}

\section{A. Lokasi Penelitian}

Lokasi penelitian ini berada di perairan Teluk Jakarta, Provinsi DKI Jakarta. Pada penelitian ini membatasi pemodelan pada koordinat $5^{\circ} 54^{\prime}-6^{\circ} 80^{\prime}$ LS dan 106 $30^{\prime}$ $107^{\circ} 20^{\prime}$ BT. Lokasi penelitian ditunjukkan pada Gambar 1. 


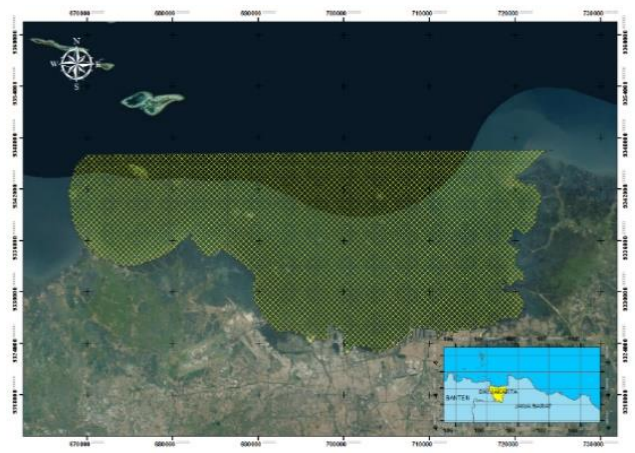

Gambar 1. Lokasi Penelitian

\section{B. Data dan Peralatan}

\section{1) Data}

Data yang digunakan dalam penelitian ini meliputi peta batimetri Teluk Jakarta tahun 2015, data pasang surut Stasiun Tanjung Priok bulan Januari dan September tahun 2011 untuk simulasi pra reklamasi. Data pasang surut Bulan Februari dan Mei tahun 2016 untuk simulasi pasca reklamasi. Masterplan reklamasi 17 pulau, data river discharge lima sungai yang bermuara ke Teluk Jakarta tahun 2011 dan 2016, dan data curah hujan harian tahun 2011 dan 2016.

\section{2) Peralatan}

Peralatan yang digunakan pada penelitian ini meliputi: Perangkat Lunak (Software) yaitu AutoCad landesktop 2009, Software editting mesh, Software pemodelan arus dan sedimen, Software untuk konversi data dxf ke xyz.

\section{Tahapan Pengolahan Data}

Pada tahapan awal pengolahan data dalam penelitian ini adalah dengan melakukan retifikasi dan digitasi terhadap peta raster Teluk Jakarta menggunakan software autocad landesktop 2009. Dari hasil digitasi peta tersebut akan diperoleh hasil pengolahan berupa data batimetri, data garis pantai, dan data reklamasi teluk jakarta dalam bentuk vektor (.dxf). Kemudian data format .dxf yang telah diperoleh dilanjutkan dengan melakukan konversi data ke format .xyz untuk dapat diolah dalam software pemodelan yang akan digunakan. Selain itu, beberapa data yang perlu untuk dilakukan pengolahan adalah data river discharge, curah hujan, dan pasang surut yang dikonversi dari format .xyz menjadi format .dfs0, tetapi khusus pasang surut diubah menjadi format .dfs1. Format tersebut akan digunakan untuk keperluan pemodelan arus dan sedimen. Tahapan berikutnya merupakan yaitu proses building mesh. Pada tahapan ini diperlukan data garis pantai dan batimetri sebagai data masukan (untuk kondisi pra reklamasi), dan data masterplan reklamasi sebagai tambahan data (untuk kondisi pasca reklamasi). Model data menggunakan TIN (Triangulated Irregular Network) yang lebih responsif terhadap bentuk garis pantai yang tidak teratur dibandingkan dengan menggunakan bentuk grid, terlebih TIN lebih akurat dalam menyajikan data permukaan bumi, keperluan ruangan penyimpanan yang lebih sedikit, dan dapat lebih baik dalam memodelkan data kedalaman. Beberapa proses editting mesh yang dilakukan sebelum mendapatkan bentuk mesh yang diharapkan adalah dengan cara memperhalus batas-batas daratan, memperhalus dan memperbaiki jaring-jaring. Pada penelitian ini digunakan aturan untuk sudut terkecil pada masing-masing segitiga kurang dari 30 derajat, dan luas minimal setiap segitiga lebih besar dari $20 \mathrm{~m}^{2}$. Selain itu, menentukan dan mengientifikasi boundary condition area penelitian. Pada penelitian ini digunakan 7 batas meliputi 1 batas laut, 1 batas daratan, dan 5 batas sungai.

Setelah kedua mesh (mesh pra dan pasca reklamasi) telah berhasil dibentuk maka dilanjutkan dengan proses simulasi pemodelan arus dan sedimen. Simulasi dilakukan pada 4 kondisi, yaitu pra reklamasi (musim penghujan dan kemarau) dan pasca reklamasi (musim penghujan dan kemarau) dengan masing-masing pemodelan menggunakan time step 900 detik. Untuk pemodelan pra reklamasi, pada Bulan Januari 2011yang merupakan musim penghujan, simulasi dilakukan selama 31 hari dengan timestep yang digunakan selama 5 hari. Sedangkan pada Bulan September 2011 simulasi dilakukan selama 30 hari dengan timestep selama 5 hari. Untuk pemodelan pasca reklamasi, pada Bulan Februari 2016 lama simulasi dilakukan selama 29 hari dengan 5 hari sebagai warming up, dan pada bulan mei 2016 dilakukan selama 31 hari dengan warming up dilakukan selama 5 hari.

\section{HASIL DAN ANALISA}

\section{A. Hasil editting Mesh}

Pada tahap awal pemodelan bagian yang paling penting adalah proses editting mesh. Element mesh secara otomatis terbentuk berdasarkan data garis pantai dan boundary condition yang telah ditentukan. Pada saat proses editting mesh, modifikasi mesh dilakukan secara manual untuk melakukan pemindahan titik, merging triangular elements, pengahalusan batas-batas daratan lautan dan proses editting lainnya. Berikut ditampilkan hasil editting mesh baik pra maupun pasca reklamasi. Jumlah elemen yang dihasilkan pra reklamasi sebanyak 4236 elemen, dan pasca reklamasi sebanyak 4484 elemen.

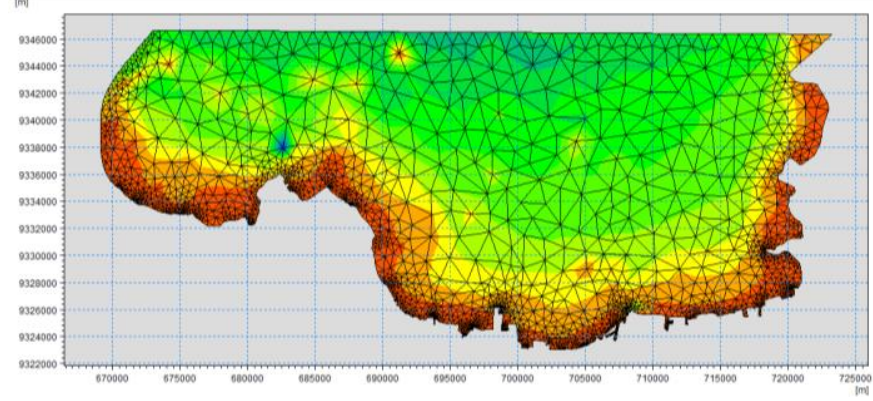

Gambar 2. Hasil Editting Mesh Pra Reklamasi

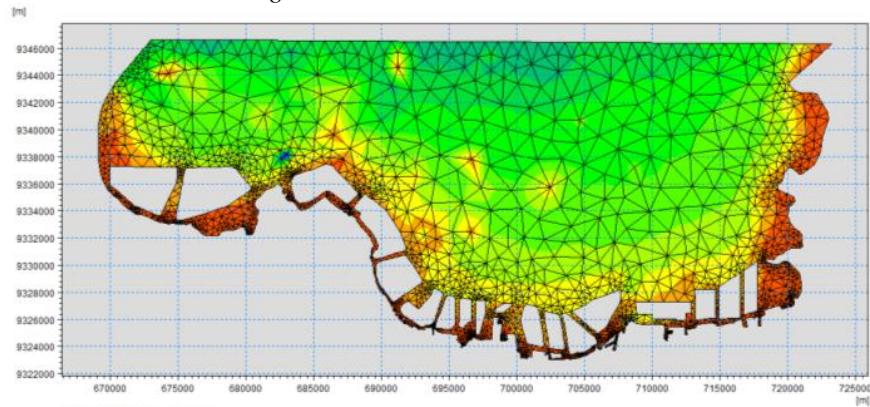

Gambar 3. Hasil Editting Mesh Pasca Reklamasi 


\section{B. Hasil Pasang Surut}

Pada penelitian ini, data pasang surut yang dipakai adalah data pasang surut Stasiun Tanjung Priok pada koordinat $06^{\circ} 05^{\prime}$ $45^{\prime \prime} \mathrm{S}-106^{\circ} 53^{\prime} 10^{\prime \prime} \mathrm{T}$ yang didapatkan dari Pushidrosal. Data pasang surut tersebut berupa data pasang surut Bulan Januari dan September 2011 (untuk simulasi pra reklamasi) dan data Bulan Februari dan Mei (untuk simulasi pasca reklamasi). Verifikasi model dilakukan dengan membandingkan hasil pengukuran pasang surut Pushidrosal dengan pemodelan. Pada Gambar 4 hingga Gambar 7 diperlihatkan grafik perbandingan antara data pasang surut Pushidrosal (garis biru) dengan data pasang surut hasil pemodelan (garis hijau).

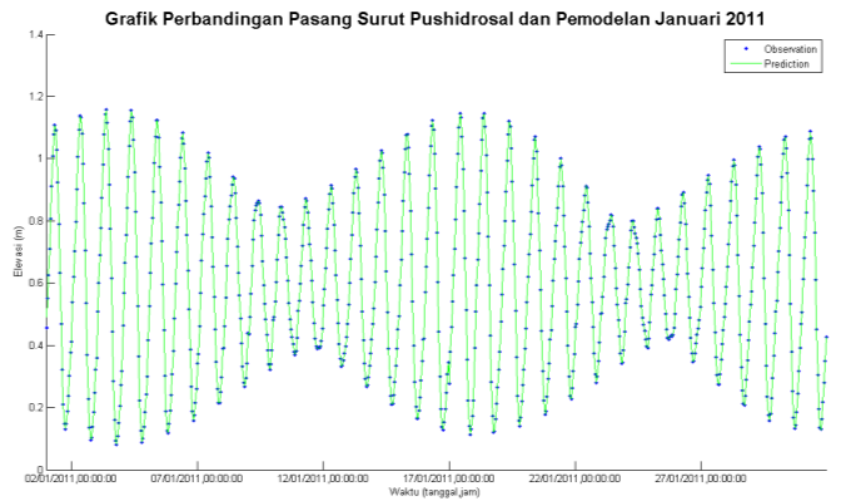

Gambar 4 .Grafik Perbandingan Data Pasang Surut Pushidrosal dengan Pemodelan Bulan Januari 2011

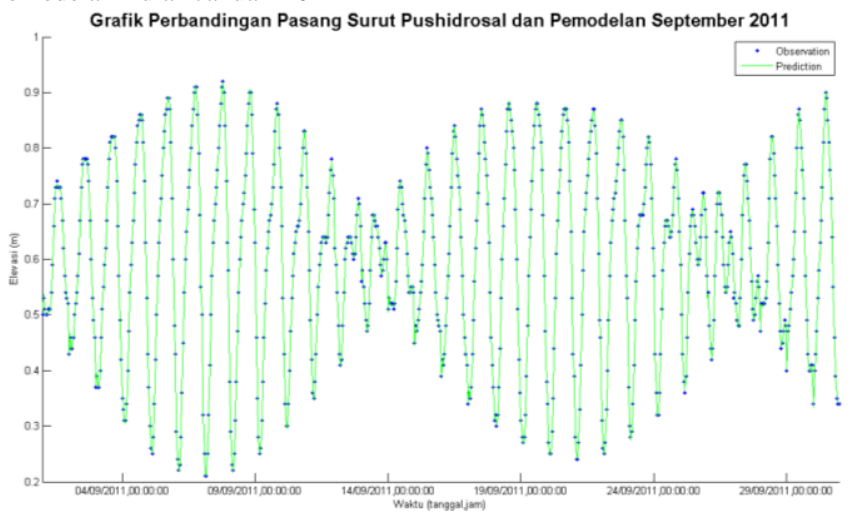

Gambar 5. Grafik Perbandingan Data Pasang Surut Pushidrosal dengan Pemodelan Bulan September 2011

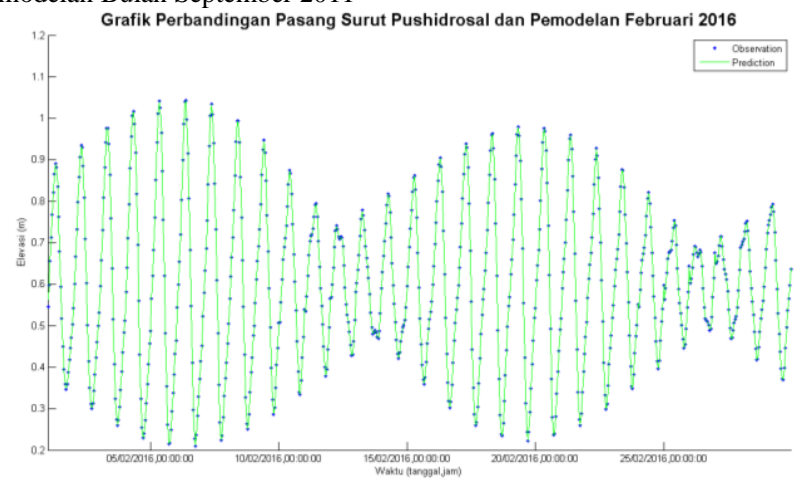

Gambar 6. Grafik Perbandingan Data Pasang Surut Pushidrosal dengan Pemodelan Bulan Februari 2016

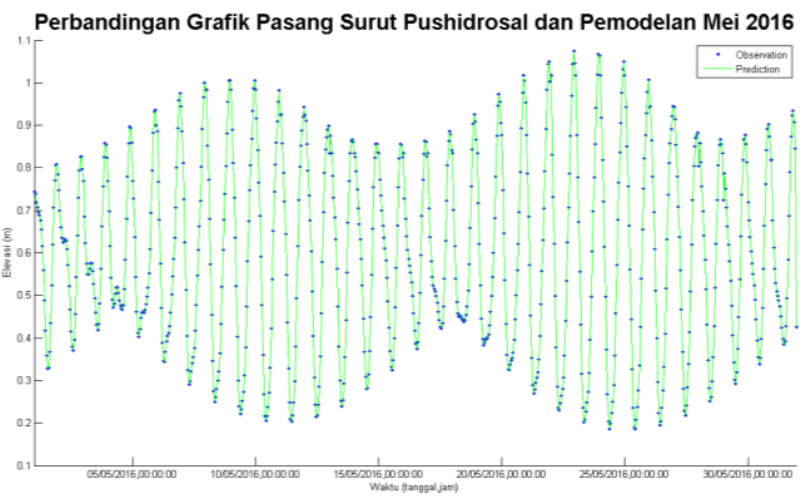

Gambar 7. Grafik Perbandingan Data Pasang Surut Pushidrosal dengan Pemodelan Bulan Mei 2011

Grafik perbandingan pasang surut pengamatan dengan pemodelan secara keseluruhan menunjukkan pola naik turun yang sama. Verifikasi model dilakukan dengan menghitung Root Mean Square (RMS Error). RMSE merupakan pengukuran yang menyatakan perbandingan antara nilai pengamatan dengan nilai pasang surut hasil pemodelan. RMS menyajikan total dari residu menjadi ukuran tunggal dari kekuatan prediksi/model [3]. Nilai RMSE dinyatakan dengan persamaan 1 berikut :

$$
R M S E=\sqrt{\frac{\sum_{i=1}^{n}\left(x_{o b s, i}-x_{\text {model }, i}\right)^{2}}{n}}
$$

dimana Xobs menyatakan nilai observasi dan Xmodel adalah nilai model; sedangkan $n$ adalah banyaknya populasi. Pada bulan Januari 2011 diperoleh nilai RMSE 0,003, pada bulan september 0,003, bulan Februari sebesar 0,007 dan pada bulan mei sebesar 0,015 . Karena keseluruhan nilai RMSE yang diperoleh $<1$, maka keseluruhan data pemodelan menunjukkan uji korelasi yang baik.

\section{Hasil Hidrodinamika (Arus)}

Hasil hidrodinamika yang diperoleh dilakukan pada saat kondisi pasang tertinggi dan surut terendah. Pada bulan Januari 2011 kondisi pasang tertinggi terjadi pada tanggal 3 Januari pukul 09.00 WIB. Saat itu kecepatan arus mencapai $0 \mathrm{~m} / \mathrm{s}-$ $0,486 \mathrm{~m} / \mathrm{s}$. Sedangkan pada kondisi surut terendah terjadi pada tanggal yang sama mencapai $0 \mathrm{~m} / \mathrm{s}-0,944 \mathrm{~m} / \mathrm{s}$. Di Bulan September 2011, pasang tertinggi terjadi pada tanggal 7 September dengan kecepatan arus berkisar antara $0-0,510 \mathrm{~m} / \mathrm{s}$ dan kondisi surut terjadi pada tanggal 7 September 2011 pukul 03.00 dengan kecepatan $0-0,930 \mathrm{~m} / \mathrm{s}$.

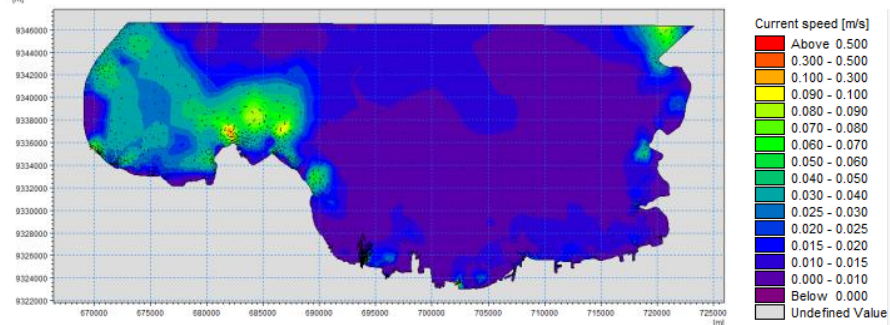

Gambar 8. Kondisi Arus Saat Surut Terendah Januari 2011 


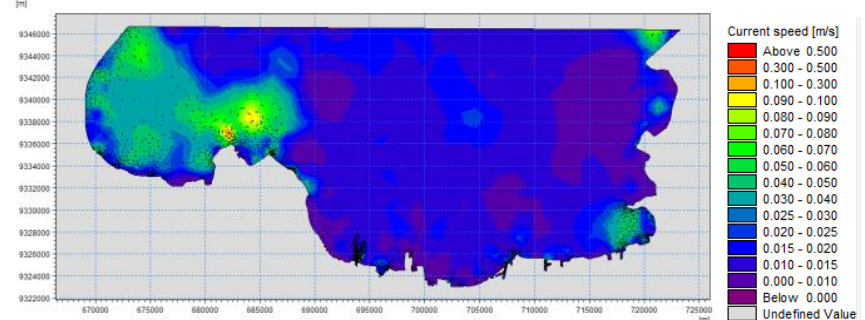

Gambar 9. Kondisi Arus Saat Surut Terendah September 2011

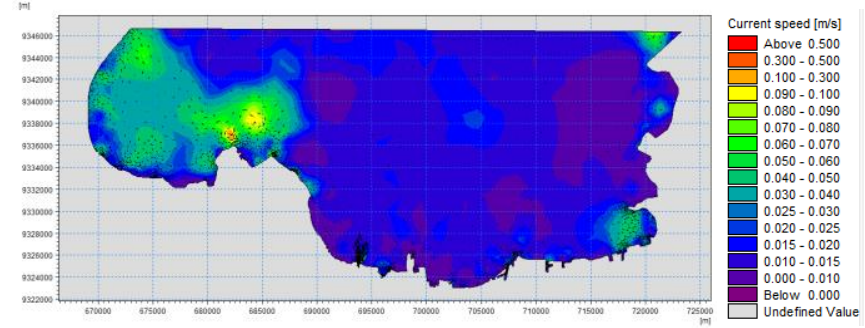

Gambar 10. Kondisi Arus Saat Surut Terendah Februari 2016

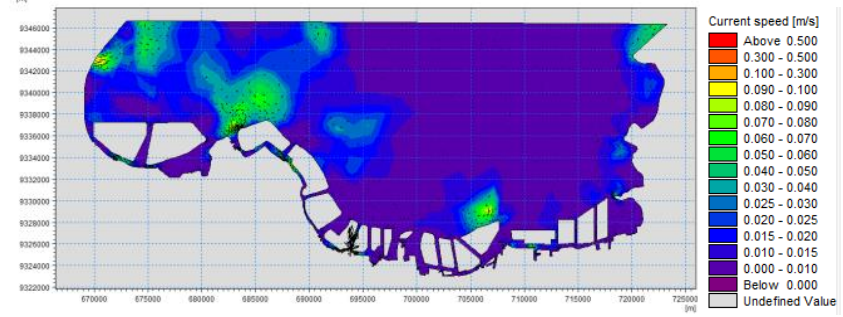

Gambar 11. Kondisi Arus Saat Surut Terendah Mei 2016

Saat pasca reklamasi, di Bulan Februari pasang tertinggi terjadi pada tanggal 6 Februari 2016 dengan kecepatan arus berkisar antara $0-0,510 \mathrm{~m} / \mathrm{s}$ dan surut terendah dengan kecepatan arus berkisar $0-0,770 \mathrm{~m} / \mathrm{s}$. Sedangkan pada bulan mei 2016, terjadi pasang tertinggi terjadi pada tanggal 22 mei 2016 dengan kecepatan arus saat pasang sebesar $0-0,540 \mathrm{~m} / \mathrm{s}$ dan saat kondisi surut sebesar $0-0,880 \mathrm{~m} / \mathrm{s}$.

Model simulasi perairan Teluk Jakarta pasca diadakan reklamasi menyebabkan adanya partisi arus-arus kedalam kanal-kanal pulau reklamasi. Diantara pulau-pulau reklamasi terdapat celah - celah sehingga menyebabkan intensifikasi arus kedalam celah yang sempit. Berdasarkan hasil simulasi yang diperoleh, secara keseluruhan dilaksanakannya proyek reklamasi di Teluk Jakarta menyebabkan penurunan nilai kecepatan arus di lokasi penelitian. Pada saat pra reklamasi, kecepatan arus permukaan dibagian selatan Teluk pada saat musim penghujan berkisar antara $0-0,944 \mathrm{~m} / \mathrm{s}$ dan saat musim kemarau berkisar antara $0-0,930 \mathrm{~m} / \mathrm{s}$. Sedangkan pasca reklamasi, kecepatan arus menjadi $0-0,770 \mathrm{~m} / \mathrm{s}$ saat musim penghujan dan $0-0,880 \mathrm{~m} / \mathrm{s}$ saat musim kemarau.

\section{Sedimen Tersuspensi}

Hasil sedimen tersuspensi pada Teluk Jakarta secara keseluruhan berada pada kisaran nilai $0-0,11 \mathrm{mg} / \mathrm{l}$ saat Bulan Januari 2011. Pada Bulan September 2011 terjadi penurunan sedimen tersuspensi berada pada kisaran $0-0,02 \mathrm{mg} / \mathrm{l}$, hal tersebut disebabkan karena rendahnya intensitas hujan pada bulan September 2011 yang hanya mencapai 10 mm/bulan sehingga sedimen tersuspensi yang terbawa arus akan lebih sedikit. Setelah diadakan reklamasi, yaitu pada Bulan Februari 2016 sedimen tersuspensi berkisar antara $0-0,032 \mathrm{mg} / \mathrm{l}$ dan kembali meningkat saat bulan Mei 2016 dengan tingkat konsentrasi mencapai $0-0,256 \mathrm{mg} / \mathrm{l}$. Lokasi yang mengalami peningkatan konsentrasi sedimen terutama berada di bagian muara sungai dan di beberapa lokasi sekitar pulau reklamasi.

Hal ini sesuai dengan Umi M dan Agus S (2002) [6]. yang mengatakan bahwa bagian sungai yang paling efektif untuk proses pengendapan (sedimentasi) adalah bagian hilir atau pada bagian slip of slope pada kelokan sungai. Ukuran material yang diendapkan berbanding lurus dengan besarnya energi pengangkut, sehingga semakin ke hilir, energi semakin kecil, material yang diendapkan pun semakin halus. Secara keseluruhan, pada saat kondisi pasang tertinggi pola sedimentasi kurang bervariasi, hal ini dikarenakan tekanan yang berasal dari arus yang menuju kedalam teluk. Secara pola, konsentrasi sedimen semakin berkurang saat menjauhi teluk dan muara sungai. Secara umum konsentrasi sedimen semakin rendah saat menjauhi muara sungai dan menuju ke tengah atau keluar teluk [7].

\section{E. Sedimen Kohesif}

Untuk melakukan uji sedimentasi pada data hasil pemodelan maka ditentukan 7 lokasi yang dipilih sebagai sample acak penelitian. Lokasi sample tersebut dipilih untuk mewakili keseluruhan lokasi penelitian. Lokasi sample acak di gambarkan pada Gambar 12 berikut

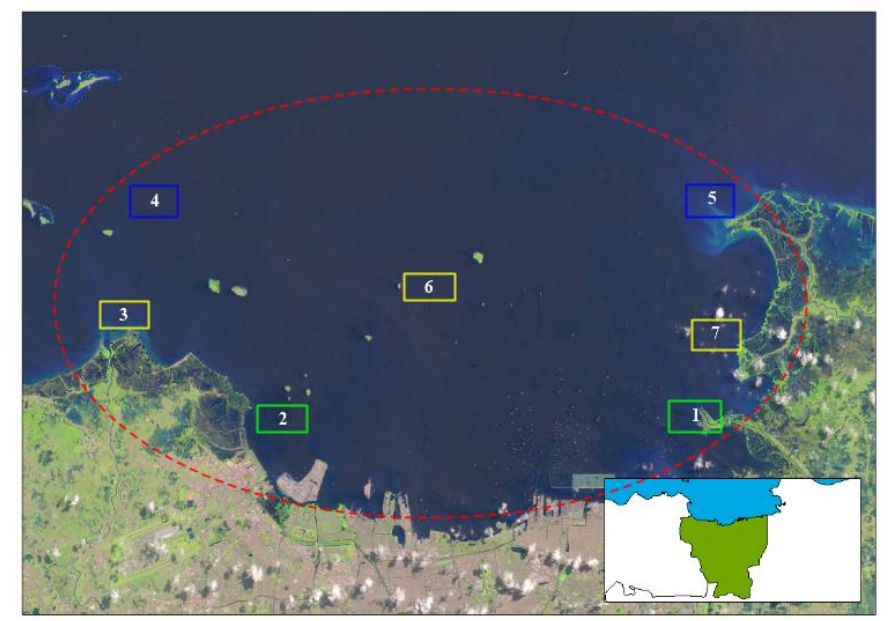

Gambar 12. Sample acak untuk mengetahui parameter sedimen kohesif

Parameter yang digunakan untuk mengetahui nilai sedimen kohesif dilokasi penelitian antara lain bed shear stress, deposisi, dan erosi. Stasiun 1 dan 2 merupakan stasiun yang mewakili daerah selatan yang terdekatan dengan lokasi reklamasi, Pada stasiun 1 nilai deposisi deposisi maksimum pra reklamasi yaitu sebesar $0,836 \mathrm{~kg} / \mathrm{m}^{2} / \mathrm{s}$ dari nilai sebelum pra reklamasi hampir tidak terjadi deposisi yaitu bernilai 0,382 $\mathrm{kg} / \mathrm{m}^{2} / \mathrm{s}$. Pada stasiun 2 terjadi peningkatan nilai bed shear stress dari $0,405 \mathrm{~N} / \mathrm{m}^{2}$ menjadi $0,481 \mathrm{~N} / \mathrm{m}^{2}$.

Stasiun 3, 6 dan 7 merupakan stasiun yang mewakili bagian tengah dari lokasi penelitian. Pada stasiun 3 terjadi peningkatan nilai bed shear stress yang dari angka $0,063 \mathrm{~N} / \mathrm{m}^{2}$ menjadi $0,085 \mathrm{~N} / \mathrm{m}^{2}$. Pada stasiun 6 memiliki nilai bedshear stress sebesar $0,004 \mathrm{~N} / \mathrm{m}^{2}$ sedangkan pasca reklamasi meningkat menjadi $0,062 \mathrm{~N} / \mathrm{m}^{2}$. Pada stasiun 7 perubahan deposisi perairan meningkat dari $0,024 \mathrm{~kg} / \mathrm{m}^{2} / \mathrm{s}$ menjadi $0,074 \mathrm{~kg} / \mathrm{m}^{2} / \mathrm{s}$. 
Pada sample 5 dan sample 4 hampir tidak terjadi peningkatan nilai deposisi atau erosi yang signifikan.

Dari hasil simulasi yang didapatkan, perubahan sedimen maksimum yang terjadi di lokasi penelitian didapatkan pada saat pra reklamasi saat musim kemarau yaitu pada bulan September 2011, nilai ketebalan sedimen dasar perairan mencapai $0,84 \mathrm{~m}$. Sedangkan pasca diadakannya reklamasi, peningkatan ketebalan dasar perairan mencapai $2,49 \mathrm{~m}$. Peningkatan terjadi terutama dilokasi muara sungai dan diantara pulau-pulau reklamasi. Seperti diketahui, sumber utama dari adanya sedimentasi berasal dari river discharge sehingga data kelima sungai yang digunakan dalam pemodelan memiliki dampak signifikan pada persebaran peningkatan sedimen terutama di Sungai Pesanggrahan dan Sunter, terlebih bila dilakukannya pembangunan pulau-pulau reklamasi. Dampaknya jika terjadi peningkatan sedimentasi di perairan Teluk Jakarta adalah proses laju pendangkalan akan lebih cepat terjadi mengingat Teluk Jakarta termasuk kedalam perairan dangkal dimana pendangkalan tersebut dapat mengganggu aktivfitas-aktifitas lainnya.

\section{KESIMPULAN}

Berdasarkan pengolahan dan analisis data yang telah dilakukan, berikut adalah kesimpulan yang penulis dapatkan dalam penulis studi ini.

1. Pada saat pra reklamasi, kecepatan arus dibagian selatan Teluk berkisar antara $0-0,94 \mathrm{~m} / \mathrm{s}$, Sedangkan pasca reklamasi, kecepatan arus menurun menjadi $0-0,88 \mathrm{~m} / \mathrm{s}$. Penurunan nilai kecepatan arus rata-rata setelah diadakan reklamasi salah satunya disebabkan karena panjangnya aliran arus yang harus dilalui mengikuti bentuk pulaupulau reklamasi sehingga arus mengalami penurunan energi kecepatan.

2. Perubahan sedimen maksimum yang terjadi di lokasi penelitian didapatkan pada saat pra reklamasi saat musim kemarau yaitu pada bulan September 2011, nilai ketebalan dasar perairan mencapai $0,84 \mathrm{~m}$. Sedangkan pasca diadakannya reklamasi, peningkatan ketebalan dasar perairan mencapai 2,49 m. Peningkatan sedimentasi terjadi terutama berada di Muara Cengkareng dan Kali Sunter.

3. Dengan diadakannya proyek Reklamasi di Teluk Jakarta menimbulkan permasalahan utama yaitu terjadinya penurunan nilai kecepatan arus secara keseluruhan pada area penelitan. namum terjadi peningkatan arus pada beberapa lokasi disekitar pulau reklamasi. Pengadaan reklamasi juga menyebabkan terjadinya peningkatan sedimen dasar perairan yang akan menyebabkan peningkatan proses pendangkalan di area penelitian.

\section{SARAN}

Berdasarkan hasil penelitian yang dilakukan, berikut merupakan saran yang dapat penulis berikan dalam penulisan studi ini.

1. Diperlukan penelitian lanjutan terkait dengan pola sedimentasi di Teluk Jakarta dengan metode baroklinik sehingga diperoleh hasil yang lebih sesuai dengan kondisi lapangan.

2. Diperlukan validasi lapangan secara langsung dengan menggunakan grab sampler dan uji sedimen tersuspensi untuk mengetahui karakteristik sedimen di Teluk Jakarta pada saat kondisi eksisting.

3. Melengkapi keseluruhan sumber sedimen yang bermuara ke Teluk Jakarta, dan menambahkan sumber lain seperti limbah-limbah hasil produksi pabrik yang langsung menuju Teluk Jakarta tanpa melalui sungai.

\section{UCAPAN TERIMAKASIH}

Penulis mengucapkan terimakasih kepada Pusat Hidrografi dan Osenaografi TNI-AL (Pushidrosal), Balai Besar Wilayah Sungai Ciliwung dan Cisadane (BBWS Cil-Cis) Kementrerian Pekerjaan Umum Provinsi DKI Jakarta dan Badan Meterologi, Klimatologi, dan Geofisika (BMKG) atas ketersediaan dalam memberikan data yang diperlukan untuk penelitian ini.

\section{DAFTAR PUSTAKA}

[1] K. K. Perekonomian, "Pengembangan Terpadu Pesisir Ibukota Negara," 2014.

[2] "Jurnal Pengolahan Hasil Perikanan Indonesia," vol. XIV, no. 1, 2011.

[3] B. A. dan Y. M. Lubis, A.A., "Estimasi Laju Akumulasi Sedimen Daerah Teluk Jakarta dengan Teknik Radionuklida Alam," vol. 7, no. 3, pp. 309-313, 2007.

[4] Peraturan Daerah Provinsi Daerah Khusus Ibukota Jakarta Nomor 1 Rencana Tata Ruang Wilayah 2030. Jakarta, 2012.

[5] R. and Kowalik, "Numerical Modelling of Marine Hydrodynamics," J. Hydraul. Res., 1980.

[6] U. M. dan S. Agus, Pengantar Kimia dan Sedimen Dasar Laut. Badan Riset Kelautan Dan Perikanan, 2002.

[7] and A. C. N. Sravanthi. N., R. Ramakrishnan, A.S. Rajawat, "Application of numerical model in suspended sediment transport studies along the Central Keral," Aquat. Procedia, pp. 109-116, 2015. 